\title{
The Politics of Whitelisting Regulatory Work and Topologies in Commercial Security
}

\author{
Leander, Anna
}

Document Version

Accepted author manuscript

Published in:

Environment and Planning D: Society and Space

DOI:

$10.1177 / 0263775815616971$

Publication date:

2016

License

Unspecified

Citation for published version (APA):

Leander, A. (2016). The Politics of Whitelisting: Regulatory Work and Topologies in Commercial Security.

Environment and Planning D: Society and Space, 34(1), 48-66. https://doi.org/10.1177/0263775815616971

Link to publication in CBS Research Portal

\section{General rights}

Copyright and moral rights for the publications made accessible in the public portal are retained by the authors and/or other copyright owners and it is a condition of accessing publications that users recognise and abide by the legal requirements associated with these rights.

Take down policy

If you believe that this document breaches copyright please contact us (research.lib@cbs.dk) providing details, and we will remove access to the work immediately and investigate your claim. 


\section{The Politics of Whitelisting: Regulatory Work and Topologies in Commercial Security Anna Leander}

Journal article (Post print version)

\section{This article was originally published in Environment and Planning D: Society and} Space, Vol 34, Issue 1, Pages 48-66.

First published online December 6, 2015.

DOI: 10.1177/0263775815616971

Uploaded to Research@CBS: March २०16 


\title{
The Politics of Whitelisting: Regulatory Work and Topologies in Commercial Security
}

\author{
Abstract \\ This article looks closely at the politics of whitelists in commercial security. It argues that whitelists are \\ essential for the current transformations in regulatory politics in which Codes of Conduct, Best Practices, \\ Benchmarks and Standards are replacing more conventional, legally binding forms of regulation. The article \\ traces how whitelists are tied to these transformations. The account is organized around how the practical, \\ pragmatic, and poetic character of lists (Umberto Eco) fashion the work and topological imprint (Manuel \\ DeLanda) of whitelists in commercial security specifically. The article directs attention to the politics the work \\ and topological imprint of whitelists. This politics is neither hidden nor invisible yet it remains largely unnoted. \\ It is dispersed, mundane and unspectacular; the whitelists are akin to minions whose activities are turning \\ softly regulated commercial security into an infernal alternative (imagery borrowed from Pignarre and \\ Stengers). As minions, whitelists appear insignificant when looked at in isolation. However, by describing their \\ work as a decentralized, disjointed and disorganized group, this article shows their significance for the politics \\ of regulation in commercial security. It advances a conceptualization of this politics and a theorization of its \\ dynamics of relevance for engaging the politics of lists also elsewhere.
}

\section{Acknowledgements}

Thanks to the many people from the busy world of commercial security regulation who took time to talk to and e-mail me. Special thanks to Andre du Plessis, Charles Chadwick, and Rebecca de-Winter Schmitt for their generous engagement. Comments from the participants in the working group III meeting of COST Action IS1003 and especially Marieke de Goede and Wouter Werner are gratefully acknowledged, as are the comments by Ester Baringa, Ole Bjerg, Christian Borch and Antje Wiener, the team at EPD and two anonymous reviewers.

Key words: Lists, commercial security, material agency, topology, new materialsm 
This article is about the politics of whitelisting in commercial security. It argues that the whitelists of companies, states and organizations that have signed up to the codes of conduct, best practices, benchmarks and standards now regulating commercial security have far-reaching political significance. These whitelists do core regulatory work, and in the process they leave deep imprints on the regulatory landscape (or topology) of commercial security. Whitelists make soft, voluntary regulation of commercial security practically feasible and difficult to contest. They enshrine and normalize both this form of regulation and the security markets it is tied to.

The politics of whitelists in commercial security has much in common with that of the minions in Pignarre and Stengers' account of the "spell of capitalist sorcery" (2011). As these minions, whitelists produce the "infernal alternatives" necessary for the "spell of capitalist sorcery" to work, that is "alternatives" that offer no alternative at all because they "seem to leave no other choice than resignation or a slightly hollow sounding denunciation" (2011: 24). As the politics of the minions, that of the whitelists is easily overlooked and correspondingly hard to engage. As the minions, whitelists operate in a decentralized fashion "on a very small scale", of which the "infernal alternatives are an overall result" (Pignarre and Stengers, 2011: 31). Viewed in isolation, the work and imprint of each whitelist/minion is therefore bound to appear innocuous, insignificant and unworthy of attention even if it is neither well intentioned nor innocent. To describe how the dispersed, small-scale labour and imprint of whitelists/minions collectively produce an "infernal alternative", to name them as the guardians of this alternative, and to highlight their politics is therefore of essence. It is a way of encouraging political disagreement and imagination. In this case, it is about opening up for the contestation of the whitelists that turn soft, voluntary regulation of commercial security markets into an infernal alternative and hence for the possibility of imagining alternative ways of regulating the security.

The politics of whitelisting may be easy to miss. However, discovering it does not require any looking "behind" or "beyond". No hidden centre, capitalist class or elite of security professionals is masterminding the production of "infernal alternatives" by whitelists in a conspiracy that could be exposed and dismantled. They are no doubt involved, but in a far less unified and exiting way. Instead, of looking for conspiracies, describing the politics of whitelisting is therefore a matter of putting words on what is there for everyone to see. It is about drawing inspiration from the child who shocks the public by pointing out that the parading emperor is naked. Just as that description was shocking, the one offered in this article is also likely to offend many sensibilities. This includes those of the many analysts of regulation of commercial security who would find the 
idea of critically engaging the politics (rather than the efficiency) of whitelisting ludicrous, or worse, irresponsible: why undermine the most effective, and possibly only, form of regulation available? ${ }^{1}$

However, the description of the politics of whitelisting is also likely to offend the sensibilities of those who share an interest in the politics of whitelisting. First, by locating whitelists among the "minions" that make the spell of capitalist sorcery, it is endowing lists with a form of agency. While this kind of vitalism may go down well with scholars working in a new materialist tradition, it will be objectionable to many others interested in the politics of regulation in contemporary markets. Second, by insisting on critically engaging the politics of these whitelists, the account also risks offending many new materialists. This account makes visible the politics of whitelisting in commercial security. It blurs the comfortable lines separating the "riddle" from the "complot" (Boltanski, 2012) and could readily be accused of being "conspiratorial". Even if it is not, it certainly betrays the "Leibnizean ethos" of much new materialist scholarship that we should not "reverse established sentiment" but instead content ourselves with inventing a vocabulary and prying open perspectives that might allow a questioning and a redefinition of these from within (Stengers, 1995: 25). ${ }^{2}$ The account here aims at "reversing established sentiment" by describing the much neglected place, power and responsibility of whitelists in the politics of commercial security.

The argument is organized in three parts. The first outlines its basic terms. It introduces the whitelists in commercial security, their practical, pragmatic and poetic characteristics, and the rationale for observing their work and topological imprints. The second and third sections explore their regulatory work and topological imprints by focussing on these three characteristics. The argument is that the core role of the regulatory work of whitelists conspires with the form of their topological imprint to displace criticism and, even more strongly, they pre-empt it from emerging. They make soft- or self-regulated commercial security appear as an "'infernal alternative' ... that seems to leave no other choice than resignation or a slightly hollow sounding denunciation". As the article concludes, acknowledging this and hence opening up for a political contestation of the work done by whitelists is the only way of opening up for more appealing, non-infernal, alternatives.

\footnotetext{
${ }^{1}$ This is one of the most common responses to critiques of soft regulation in commercial security. For an authoritative example, see Dickinson (2005).

${ }^{2}$ As Stengers puts it: “La contrainte Leibnizienne selon laquelle la philosophie ne doit pas se donner pour idéal de renverser les sentiments établis... mais plutôt inventer les mots qui permettent de rendre discutable cette référencé, de fait politique, à la science... afin de pourvoir tenter de les ouvrir à ce que leur identité établie leur impose de refuser, de combattre, de méconnaitre" (1995: 25).
} 


\section{Looking Closely at Whitelisting in Commercial Security}

Before engaging the description of the politics of whitelisting, this section introduces its basic terms. It begins by explaining what is meant by "whitelist". It then proceeds to introduce the three oft-noted characteristics of lists, white or otherwise, that will guide the description to follow: their capacities to abstract, link and remain open. The last section introduces the rationale for describing the politics of lists by looking closely at the regulatory work they do and the imprint they leave on regulatory topographies.

\section{Whitelists in Commercial Security}

As this special issue underscores, lists are omnipresent in a wide range of forms and political roles. The kinds of lists dealt with here are whitelists in commercial security. The emergence and growing centrality of these whitelists is closely tied to the development of Codes, Best Practices, Benchmarks and Standards (COBBES henceforth). COBBES are hailed as the most (or only) effective response to the complexity of regulating contemporary markets in general. Their malleable, fluid or "soft" form, it is suggested, makes them ideal for handling the many legal and regulatory "contradictions", "paradoxes" and "dissonances" generated by activities that span a range of regulatory spaces (e.g. Fischer-Lescano and Teubner, 2004; Stark et al., 2009; Teubner, 2011). In commercial security, the value of COBBES is further heightened, as they circumvent the political sensitivities that mar all and any regulatory initiative in the area. "The very fact of privatization - with its hybrid public-private character - may open up alternative avenues of accountability beyond the formal instruments of international law", as Dickinson puts it (2005: 141). In commercial security, governments, international organizations, NGOs, Interest groups and companies have therefore elaborated a minor forest of standards and codes of conduct (Leander, 2009).

The lists this paper deals with show who has signed up to a specific set of COBBES. In the article, these lists are referred to as whitelists and often in the plural. The reason for the plural is that the article is intent on describing how they (in plural as a horde of minions) transform regulatory politics. This plural does not imply that all whitelists in commercial security lists are the same. They are not. Lists are published by the sponsors of a set of COBBES to show who is committed to them, as well as by companies or organizations to inform what COBBES they have signed up to. These lists refer to a wide range of issues and contexts and therefore are very different, not only in terms of what they are referring to, but also in terms of which entities figure on them and 
what kind of structure and length they have. This said, the lists in plural can have effects collectively, like other entities that are diverse internally, including NGOs, political parties, companies or states.

But why whitelists? The lists in commercial security are positive lists. There are no negative blacklists. The lists indicate what companies and organizations have signed up to what COBBES. Figuring on these lists provides "a particular privilege, service, mobility, access or recognition" the nature of which obviously varies with the COBBES. Being committed to a set of COBBES may be a precondition for competing for a contract or it may just be a matter of demonstrating that one deserves to be "considered acceptable or trustworthy". Either way, this combination of a particular privilege and a status as acceptable and trustworthy is the dictionary definition of a whitelist (Oxford Dictionary online; also Bedford in this issue). It is important to note that in commercial security this whitelisting does not signal anything beyond an expressed commitment. However, even so, figuring on the lists is the source of privileges and a token of trustworthiness. Disregarding this by not terming the lists pertaining to the COBBES in commercial security whitelists would be misleading and biased.

\section{Three Characteristics of Lists}

To describe the politics of these whitelists, the account below focuses on three interrelated general characteristics of lists that figure prominently in more general discussions of lists and (therefore) also recur in the other articles in this special issue, namely that lists rely on discontinuity and abstraction from context, that they can (therefore) connect these contexts, and that they orient towards the future in suspending conflict and contradictions in the present. Another way of summarizing these characteristics is to follow Eco, who distinguishes between practical, pragmatic and poetic lists (2009: 113).

First, to the practical character of lists: as Goody points out in his account of why lists have been core to the development of abstract cultures based on writing from the Sumer to our own, it is because "the list relies on discontinuity rather than continuity" (Goody, 1977: 81). His general point is that lists escape the embedded, embodied, narrative and contextual. Working by discontinuity makes it possible to compile and link things according to abstract, flexible and possibly changing classificatory schemes. According to Goody, lists are therefore central to the development of complex economic and state organizations and to the specific form of abstract and classificatory thinking that accompany these. Lists can be searched and information retrieved without first disengaging and disentangling it from a sticky and complicating context precisely because they abstract from otherwise complex, heterogeneous, contradictory and conflicting information. Bringing out the politics of this "invisible work" of abstracting is at the heart of Staeheli's treatment of lists (2012 and this issue). 
Borges famously used lists precisely to bring together the seemingly inconsistent and unrelated. ${ }^{3}$ Similarly, to include the heterogeneous content that he thinks is needed to understand the Columbian drug trade without having to impose a single logic on it, anthropologist Taussig relies on a list to provide an inventory of what he terms “My Columbian Cocaine Museum” (2004). As Borges' and Taussig's lists indicate, lists work through discontinuity, abstracting from context. This allows them to take on an essential, compiling, role. They are practical, in Eco's terms.

Related to this is a second characteristic of lists, namely that lists often work to link and relate diverse and perhaps contradictory and incompatible contexts. Because they are abstract, lists can also be acceptable across contexts. They can work as "boundary objects", spanning the boundaries between contexts and hence linking them while taking on different and perhaps contradictory roles in each. As Star insists, precisely this is a key (frequently overlooked) role of boundary objects. According to her, boundary objects make it possible to have "a sort of arrangement that allows different groups to work together without consensus" (Star, 2010:602). Lists function similarly. They can pragmatically (to use Eco's terminology again) link different contexts without being marred by their contradictions and incompatibilities. The pragmatism of lists makes it possible for them to occupy a fore place in a "Global Law" in which "lists plus algorithms" are "conduits", "shortcuts" and "objects" (Johns this issue). More generally, the fact that boundary objects link contexts often makes them the fall-back option, something relied upon by default as it were. "When an object [in this case a whitelist] becomes naturalized in more than one community of practice, its naturalization gains enormous power, to the extent that a basis is formed for dissent to be viewed as madness or heresy" (Bowker and Star, 2000: 312).

The tendency to accept lists and allow them to become a "natural" part of a context is reinforced by a third characteristic of lists, namely their openness and future orientation. Because lists work by disconnection and by tying contexts together, lists seem to follow an open-ended "logic of the ands" (Fuller, 2005). Additions can be made. The criteria for adding to the list may be rethought and revised. This makes the list at least potentially follow a "logic of infinite addition" (Staeheli, 2012; as well as Weber and de Goede and Sullivan in this issue). As Eco puts it: A book about lists "cannot but end with an etcetera" (2009: 7). This openness and future orientation make lists appear full of potential. They direct attention away from an inscrutable

\footnotetext{
${ }^{3}$ Foucault, Hacking and Staeheli are only some of the scholars drawing on Borges with reference to his reliance on listing. For a discussion centred on the insights to be gained for politics in the age of digital media, where everything is lists, see Palma (2010).
} 
present/past towards an open future. They evoke the ineffable as Eco emphasizes when discussing the poetic character of lists (2009, passim). The list is "seductive" to a point where even those observing its politics are prone to be seduced and describe lists in almost lyrical terms (Staeheli, 2012: 238-240). Eco is certainly seduced by lists. As he explains to his readers he "did not hesitate for a second, and proposed the list" when given a free hand by the Louvre to select a theme to work with in 2009 (Eco, 2009: 7).

These three characteristics do not mark all lists in the same way. "There are lists and lists" (Eco, 2009: 112-130). A shopping list is no pragmatic enumeration and no approximation of the ineffable. This is no less true in commercial security than elsewhere. There are few lists that would immediately strike observers as poetic in commercial security. However, lists are not of one or the other kind. Rather, the three recurring characteristics of lists are interlinked and overlapping in a myriad of changing ways depending on the situation. The shopping list may have more in common with the approximation of the ineffable than we usually think. It may be not only practical but also a poetic expression of potential future relationships and bonds (Miller, 1998) or also a pragmatic part of a more general to-do-today list. The characteristics of lists are therefore neither pure nor essential nor unchanging. This is as true of whitelists in commercial security as of other lists. However, to bring out the politics of whitelisting, I direct attention to the significance of one characteristic at the time: that is to the practical, pragmatic and poetic sides of lists.

\section{Tracing the Politics of Whitelist through their Regulatory Work and Topological Imprint}

Conceiving of lists as doing politics may be controversial. It involves a contention that lists are not simply used, mobilized, or interpreted in various ways that have political consequences, but that they are actually doing politics. Lists "come alive" (Leyshon and Thrift, 2009). One way of insisting on this point is to present lists as "actants". The idea of actants has been popularized through the work of Bruno Latour, who borrowed it from literary analysis, where it refers to someone or something that makes things happen in an account. The attractiveness of the term is that it makes the symmetry between the material and the human explicit. It opens up for conceiving of material objects, such as the whitelists in this article, as having a form of "agency" that is of course distinct from human agency in many ways. It does not involve the same kind of cognitive, emotional and more generally psychic processes as human agency. However, the agency of lists remains symmetrical in that they can make things happen and can therefore also be held co-responsible for political developments. Obviously (and again symmetrically to human actants), they do so in a context as part of an "agencement" or a "network" or a field (Callon, 2008: 35 ff; Latour, 2005: 54 passim; Leander, 2013). 
The question then becomes how to best engage the politics that these actants are part of making happen. For the purpose of this article, I distinguish between the politics that inheres in the regulatory work of the actants/whitelists and the imprint the actants/work leave on the regulatory topology more generally. This distinction is inspired by work in the Deleuzian tradition (where Stengers also locates her work). More specifically, it stems from Manuel DeLanda's distinction between "assemblage" and "topology" (2006), where assemblage captures the actual (the work done by lists) and topology the folding of the present into the future (the imprint of this work). The two are obviously linked. However, as DeLanda puts it:

Assemblage theory is not conceptual but causal, concerned with the actual mechanisms operating at a given spatial scale. On the other hand, the topological structure defining the diagram of an assemblage is not actual but virtual and mechanism independent, capable of being realized in a variety of actual mechanisms, so it demands a different form of analysis (DeLanda, 2006: 31).

This "different form" of analysis is one focussed primarily on understanding what DeLanda calls the "attractors" that mark the topology. These attractors give the topology its shape by structuring the "phase spaces" of possibility that make up the topology (DeLanda, 2006: 29). The account below works with these ideas to describe how whitelists fashion these "attractors" and the "phase spaces" of possibility, that is leave an "imprint" on the regulatory topology. It describes the mechanisms through which whitelists shape the regulatory assemblages are captured by highlighting the work they do.

To return to "breaking the spell", this article provides a description of how a specific group of minions (whitelists) do politics. It looks at how the work they do helps assemble a specific form of regulatory politics, and it looks at the imprints left by their constant activities on the regulatory topology. The politics of these whitelists is described through a focus on how three general characteristics of lists - their practical, pragmatic and poetic character - fashion their work and its topological imprint. To look ahead, the place this description will leads to is one from which it is easier to grasp, resist and refashion the role of whitelists in turning a soft- or self-regulated commercial security market into an "infernal alternative".

\section{The Regulatory Work of Whitelists}

Listing who has pledged to follow what Codes, Best Practices, Benchmarks or Standards, as whitelists in commercial security do, may seem to be a rather unlikely way of doing politics. And indeed, like many of the other lists discussed in this issue, the whitelists in commercial security are often thought of as mere tools of recording. However, if we take pause to describe how the practical, pragmatic and poetic characteristics of lists 
shape this recording, it becomes clear that the whitelists do central regulatory work. Their practical character allows whitelists to stake out and map regulatory spaces, their pragmatic character helps them link these spaces, and their poetic character helps them direct attention towards the potential of regulation. However unlikely it may sound, the whitelists in commercial security are doing politics.

\section{Staking out Regulatory Space}

The practical character of whitelists allows them to do important signposting work. They delineate the territory of the COBBES in commercial security. This is much needed. It is far from clear which COBBES apply to whom in what context. COBBES may be formulated by International Organizations, by national governments, by professional associations or by companies. In practice, therefore, a multiplicity of codes and standards coexist and overlap. In a strong manifestation of the "fragmentation of international law", COBBES relevant to commercial security seem to be in effect mushrooming. Providing an overview of these COBBES is far beyond the scope of this paper. The importance of any specific COBBES is both context specific and deeply contested. In some situations, adhering to a specific set of COBBES is turned into an obligation, and its significance is therefore relatively uncontroversial. ${ }^{4}$ In other cases, COBBES are followed because of pressures from advocacy groups, the activities of an energetic manager, or the views of a consultancy company. ${ }^{5}$ This makes the weight of the COBBES uncertain. Not surprisingly therefore, finding out which COBBES exist in any given context at a precise time and to whom they apply is exceedingly difficult. In 2007, one single company, ArmorGroup, pledged to abide by more than thirty different codes and standards (Leander, 2012: table 1). That number would certainly have been different for another company at the time and would be different for ArmorGroup/G4S today.

This disputed and unstable multiplicity of COBBES renders the practical recording work done by the whitelists in commercial security vital. The whitelists indicate who, at any given time, has pledged to abide by a specific set of COBBES. The lists signpost the regulatory space of the COBBES. A graphic illustration of the central (and growing) role of this practical work is the development of the ICoC / ICoCA websites. ${ }^{6}$ In 2013, the ICoC site featured a world map where countries were coloured according to how many signatory companies

\footnotetext{
${ }^{4}$ The US department of State for example recently began requiring ICoCA membership from their contractors https://www.fbo.gov/index?s=opportunity\&mode=form\&id=6247a35a5d9816a4b5e4f067b8758ecc\&tab=core \& cview=0

${ }^{5}$ For inroads into this vast literature on why companies adopt codes, see Gond, Kang, and Moon 2012.

${ }^{6}$ www.icoc-psp.org/ accessed 29 October 2013 and www.icoca.ch/en/contact-us accessed 23 April 2015. The International Code of Conduct was adopted in November 2010 and the ICoC Association established in September 2013.
} 
were headquartered there. This map occupied the bulk of the welcome page, visualizing the regulatory space of the ICoC. In 2015, the ICoCA had expanded the place it devoted to mapping and made the link between the maps and lists visible. As shown in illustration 1, the membership tab on the website displays the access to the searchable lists and the maps in direct connection. Both lists and maps are more refined and differentiated. It has become possible to visualize the private security companies, governments and civil society organizations separately. This emphasis on the mapping work of whitelists may be exceptionally strong on the ICoCA website. However, it usefully highlights the more general point that lists play a core role in the mapping of regulatory space, a point that is valid even if it is not fronted on the website of the COBBES the list refers to.

Illustration 1 around here

\section{Establishing Regulatory Relations}

The pragmatic character of lists makes them do a second kind of regulatory work in commercial security: that of managing relations between heterogeneous regulations. COBBES overlap not only with each other but also with other regulatory norms and legal arrangements. Administrative rules, regulations specific to companies, armed forces, states, and international organizations, as well as national and international law cover the same terrain (for an overview, see Leander, 2009). This overlapping makes the question of how to handle the tensions and contradictions inevitable. Which code, standard, benchmark, best practice, law, norm or treaty counts? What should be done in case they are conflicting? What is the hierarchy of regulatory norms to be applied? Whitelists are helpful when it comes to answering, or better evading, these fundamentally political questions. Their pragmatic character afford them the position of the intermediary, who is not directly involved in or expressing the messy conflicts and tensions that need to be resolved, between each set of COBBES and the many rules and regulations with which they overlap.

Consider the way the relationship between the ICoC and other regulations is established. The UN and some states, including the US, have made ICoCA membership a condition for contracting. They require companies to figure on the ICoCA whitelist. Companies can pledge to abide by ICoC. Concretely, this implies figuring on the ICOCA whitelist or listing the company commitment to the ICOC among its COBBES commitments. The ICoC itself refers to a range of national and international laws as well as to best practices and company codes. Figuring on the ICoCA whitelist therefore establishes links to these forms of regulation. In 
all these cases, the list makes it possible not to sort out what the exact relationship between these multiple regulatory standards is or even begin arguing about what it should be. There is no need to for the UN or the US to make explicit what they think it means for contractors to follow the ICoC or how this might relate to other obligations. It is enough to refer to the whitelist. Analogously, the reference to the whitelist makes it unnecessary for the companies to explicate how exactly the ICOC relates to other COBBES, laws and norms they follow or for the ICoCA to clarify how it views the relationship between the many kinds of laws and regulations its Code refers to.

Whitelists, in sum, open the possibility of constructing a web of linkages that tie the heterogeneous and contradictory COBBES, rules and norms into a criss-crossing web of relationships. They can do this because they pragmatically leave out the details and allow the rules and regulations they are dealing with to remain in the background. The ICoC has been used to illustrate this, but the rationale is more general. A company listing the UN Guiding principles, the US/UK Voluntary Principles, the ANSI/ASIS PSC 1-4 (PSCI 1-4) or the Defense Industry Initiative (DII) is in effect doing something analogous. It places the list as an intermediary that pragmatically circumvents the complications of having to explicate what exactly this Code, Best Practice Benchmark or Standard means, including how adjustments, tensions or conflicts that arise from abiding by its rule are handled.

\section{Prioritizing Potentiality}

Finally, their open character has made the whitelists do important work to confirm and consolidate the future orientation of regulation in commercial security. Those who promote COBBES are clear that, unlike classical law and binding rules, their regulatory norms are future oriented. As explained by the former vice president of BAE systems, who has also been directly active in developing core ethics codes," "the goal here [with the IFBEC] is to actually influence correct conduct. It is not to punish them [companies that do not follow the rule]. It is about how we get them to do the right thing" (Chadwick, 2013). COBBES emphasize "dialogue" and "selfreporting" intended to foster reflexivity and help companies become better at creatively imagining and engaging their tasks in ways conforming with the norms they are signing up to. Monitoring, policing and controlling are thought of as counterproductive for this process. They destroy the trust and engagement of the

\footnotetext{
${ }^{7}$ The DII [Defense Industry Initiative] and the IFBEC [International Forum on Business Ethical Conduct].
} 
companies that dialogue and encouragement can generate. But more fundamentally, from this perspective, monitoring, punishments and expulsions from an association miss the point. They close the future. They block the possibility of supporting processes of improvement. As those responsible for the ethics code of the ADS (AeroSpace and Defence Industries Association of Europe; Salzmann, 2013) put it:

The NGOs have been railing on about their [large defence company's] past demeanours. Our attitude is that they are setting a new bench mark in terms of corporate social responsibility behaviour policies. The new [major defence company] has very little, if any, relation to former [major defence company]. Therefore why punish someone on the basis of past misdemeanours by a previous management? We would rather have the possibility to work with them in the future.

And along very similar lines:

Take [major defense company] for example: it had major problems, major ethics issues. There was no talk of expelling them from the DII [Defense Industry Initiative on Ethics and Business Conduct]. They acted to remedy. Why would we want to expel them? We would rather assist them in remedying any weaknesses in their compliance program" (Chadwick, 2013).

The whitelists support and enshrine this orientation of regulation towards potentiality. The lists record the companies, civil society organizations and governments that pledge commitment to principles of the code in general and promise to work on realizing and developing them. They commit to a process. They do not claim that the process has been achieved. To figure on one of the lists in commercial security therefore requires very little, as acknowledged by everyone involved. "At the moment we've got a situation where companies can sign on the dotted line and say we acknowledge the standard and we want to abide by it" (Salzmann, 2013). ICoC had 708 signatory companies in 2013, of which many were not even working in the security sector (van Amstel, 2013). This is well known, and those responsible often mention it and find it problematic. It undermines the credibility of the COBBES and makes their norms appear to "lack teeth" (Katz, 2013). Yet, the moves towards a stricter approach to listing are timid. Even the ICoC Association (created in 2013), which introduced reporting and monitoring requirements, has done little to change the situation. ${ }^{8}$ For the time being, the listing practices tend to confirm and consolidate the overarching future orientation of the COBBES.

\footnotetext{
${ }^{8}$ The more active approach to listing has meant that the number of signatory companies has fallen from 708 to 156 since the association agreement was introduced. However, this does not alter the fact that signing up signals an intention to implement the ICOC. Moreover, there are a range of legal and practical difficulties involved. It is difficult to monitor
} 
The lists bolster the orientation towards potentiality also in a second way. They generate momentum and community around the COBBES. The lists are in most cases the concrete manifestation of the breadth and depth of the backing and support for the COBBES. They display who is committed to the set of COBBES besides the organization(s) that issued it. The lists hence demarcate the boundaries of the community backing a set of COBBES, and not only of its regulatory space. These communities may be very different in size and type. A company code usually rests on a community of the employees of the company, who formulated it possibly extending to the subcontractors. Other codes, such as the DII, IFBEC or the ICoC, have a varied range of signatories including states, advocacy groups, companies and international institutions. Either way, the display of commitment carried out by the list is important not only because it shows these differences among the communities but also because this display is essential for the momentum (or lack thereof) around the lists and hence for whether or not their boundaries expand or shrink. This has been the case for the ICoCA, where the reluctant enrolment of Civil Society Organizations has been prompted by the concern of being left out of a process that has seemed to gain momentum and importance. The lists' display of commitment has the same performative effect as classical political representation. It represents a community which it creates in the process of representing it. The lists produce a version of the "mystery of ministry" (Wacquant, 2005).

To sum up, the whitelists in commercial security do significant regulatory work. They signpost the regulatory space to which the COBBES apply, they help establish the relationship between the COBBES and other regulatory instruments, and they contribute to defining the community the COBBES rest on. This regulatory work is profoundly political. It weighs on what kind of rules apply where, how they are related and what kind of activities they regulate. But more than this, this regulatory work also enacts and enshrines the specific form of regulation the COBBES are tied to and the political choices that are embedded in them. It turns this form of regulation into the most feasible, useful and attractive form of regulation. Just as the minions produce the infernal alternatives necessary for the "spell of capitalism" to retain its magic, so the regulatory work whitelists do produces the "infernal alternative" of softly regulated commercial security. The next section takes this description further. It follows the imprints this work is leaving on the regulatory topology in commercial security.

commercial security both because of safety concerns and because the activities are often secretive. Moreover, there are no authorized auditors that could do the monitoring. And, finally, there are the standard questions of how to manage the overlapping and contradictory legal obligations involved (DeWinter-Schmitt, 2013). 


\section{The Imprint of Whitelisting on the Regulatory Topology}

The work of the whitelists is leaving imprints on the regulatory "topology" in commercial security. They are shaping and refashioning the wider landscape of regulatory activities, including ideas about what regulation is easy, difficult or impossible to imagine and engage in. Whitelists are altering the attractors that fashion the phase spaces of possibilities to recall the terms in which the idea of a topology was introduced above. This is an aspect of the politics of whitelisting other than the one discussed in the preceding section. Instead of focussing on mechanisms though which whitelists do politics, it focuses on describing the way whitelisting is transforming the conditions for politics (i.e. their imprint on the regulatory topology). It looks at how their activities are altering features of the topology that are particularly central to the organization of politics (the attractors). To do this, the section focuses on the imprint left by the three types of whitelist work just discussed (the staking out of regulatory space, the establishment of regulatory relations and the focus on potentiality). It highlights the way the practical work whitelists do to signpost territory has also devalued the role of evidence in regulatory debates. The pragmatic work they do to establish regulatory relations has produced a selfreferential, selective, and exclusionary expertise. Finally, the poetic listing work directing attention towards potentialities has limited the scope for contestation. The section shows that whitelists are reshaping the place of evidence, expertise and criticism in the politics of regulation.

\section{The De-valuation of Evidence}

Whitelists in commercial security have a practical, matter of fact, character. As underscored above, precisely this practical character enables list to take on an important role in signposting regulatory space. However, the practical disregard of context and complexity - the work by "discontinuity" as Goody puts it - changes the place of evidence in regulatory debate. Inherent in the practical work of abstracting is the capacity to disregard and also dismiss the relevance of contextual evidence and empirical argument about who figures on the whitelists and why. Moving from the engaged and involved to the abstract and general, to begin "seeing like an index", is at the heart of listing (as Staeheli explains in this issue). An implication is that referring to context and complexity to criticize or simply raise questions about the way lists signpost regulatory space (and work more generally) misses the point. "Evidence" of what happens in a specific case or context is irrelevant.

This is true when it comes to debate about the regulatory space established by whitelists. Including Boeing on a list of companies abiding by a code of ethical conduct in relation to corruption or Triple Canopy on an Ethics Code pertaining to the provision of security services would be very difficult if the lists could not 
abstract. Their inclusion depends on disregarding the many contextual and complex bribery incidences involving Boeing and the "Big Boy Rules" Triple Canopy reportedly draw on when dealing with civilians, independently of whether or not the accusations are warranted. Analogously, the practical capacity to work by discontinuity, to see like an index, also makes arguments referring to the complexities of the contextual appear irrelevant in the debate about the thematic scope of the regulatory space of lists. The claim that the same corruption ethics standards are adequate for companies "whether they do private security or sell Christmas decorations" (Salzmann, 2013) is much easier to make if there is no need to consider the issues involved or the consequences of disregarding ethical standards in the two areas.

The devaluation of evidence is starkly expressed in the limited opportunity there is for brining evidence to weigh upon specific whitelisting practices or the COBBES they are referring to. Institutionalized channels through which contextual evidence can be made relevant are scarce. The few COBBES that do institutionalize such channels, for example by creating complaint mechanisms, carefully guard information about their workings. The extent to which these mechanisms are functional at all is an open question. The message of the vice-president of the ICRC - that "rules should be implemented" - addressed to those gathered to celebrate the fifth anniversary of the Montreux Document ${ }^{9}$ is therefore of more general pertinence (Beerli, 2013). Even COBBES purporting to embrace auditing and monitoring processes that would valorize evidence appear to have dysfunctional institutional channels. A case in point is the reportedly rigorous US PSC 1-4 standards. ANAB/ASIS PSC1 establishes that there are to be company-level complaints mechanisms. It leaves open how these should work and to what effect. Moreover, it does not require that complaints, their outcomes or the related reports be made public. The consequence is that, even in this case, contextual evidence and complaints based on it are marginalized or become invisible. "Have a look at it [the ANAB complaint mechanism ${ }^{10}$ ]. I tried. It is impossible to find out what complaints were launched, let alone how they were handled" (de Winter-Schmitt, 2013). ${ }^{11}$ Contextual evidence when brought forward in other words disappears. It may linger on in the background but is fundamentally devalued.

Ultimately, the whitelists work only to accurately register who has committed to following the COBBES in general terms. Hence, it is not what evidence there might be regarding the actual behaviour of those figuring

\footnotetext{
${ }^{9}$ The Montreux Document established "best practices" relating to the implementation of the Geneva Conventions when contractors are involved.

${ }^{10}$ The complaint mechanism can be accessed at http://www.anab.org/feedback/complaints.aspx (accessed 29 October 2013).

${ }^{11}$ The ICoCA discussed above in note 8 is another example.
} 
on the list. "For ADS, it all depends on the sincerity of the company. If they don't give a stuff, that would be born in mind. It is better to apologize and be forgiven" as Salzmann explained (2013). There is no reference to actual behaviour, to evidence beyond a declared commitment. This systematic disregard of contextual evidence will no doubt suit some. However, no conspiracy is necessary for it to come about. The visible imprint left by the practical work of whitelists on the regulatory topology is sufficient.

\section{The Emergence of COBBES Expertise}

A second imprint left by the work of whitelists on the regulatory topology is the creation of a specific kind of expertise, a "COBBES expertise". As underscored in the discussion above, the work of the lists requires a special pragmatic quality to link the different regulatory environments. This quality needs to be developed and nurtured. It does not spontaneously emerge from the lists to those involved in regulatory activities. As in other professions, those involved in regulation defend their own turf in the overall landscape. ${ }^{12}$ There is no reason for them to enthusiastically embrace the COBBES establishing themselves, threatening their turf and worse still purporting to be masterminding the map of regulatory relationships, let alone even allow this if they had a choice.

Rather, a range of COBBES-specific pragmatic practices, involving people invested in the COBBES, and COBBES-specific documents and technologies are integral to the work COBBES do in imposing regulatory relationships. Just like the practices of any profession, and if we should believe Latour $\left(2010^{13}\right)$ of the legal and regulatory profession in particular, these practices are largely self-referential, those involved draw lessons from their work and that of their colleagues. Existing documents and technologies become the foundation for further work and developments. As the former director of the IFBEC explained:

When we created our company accountability questionnaire, we started with the parallel document from the US DII plus the TII Defense Companies Anti-Corruption Index questionnaire. We then picked and chose from those documents and added what we thought were important elements not covered by either of those sources (Chadwick, 2013).

\footnotetext{
${ }^{12}$ According to Abbott, "professions are exclusive occupational groups applying somewhat abstract knowledge to particular cases" (1988: 8).

${ }^{13}$ In a provocative argument that challenges the taken for granted understandings of science and law, Latour argues that, to a much larger extent than the sciences, law accumulates and builds on existing knowledge far more strictly than do the sciences (concluding chapter especially).
} 
The result is the emergence of what increasingly looks like a professional system revolving around the COBBES. ${ }^{14}$ This further spurns self-referentiality. We are witnessing the emergence of a specific form of "COBBES expertise". This has a significant mark on the topology of the regulatory landscape in its own right.

This self-referential expertise is inserting itself into the regulatory map and altering it in the process. It is also affecting the position of other forms of authoritative knowledge in the field and hence their possibilities of engaging in regulatory work, whether related to specific COBBES or more generally. Most obviously, the growth of a specific COBBES-related expertise weakens the standing of critics who do not wish to accept the terms of debate and who are also prone to exclude themselves. This often becomes the foundation for deploring the absence of reasonable and rational critique. Occasionally, it becomes an object of critique. The US-based feminist organization Code Pink, for example, issued a fake press release in the wake of the Nisour Square shooting stating that Blackwater was creating a new "Department of Corporate Integrity" that would put the "mercy back in mercenary" (Code Pink, 2007). Besides obviously criticizing Blackwater, this fake press release ridiculed the self-referential regulatory debate focussed largely on self-regulation through codes of conduct. It clearly stated that Code Pink was not willing to partake in a regulatory debate on those terms.

The emergence of this pragmatic regulatory expertise is not only weakening the position of critics and experts who reject and refuse to engage COBBES altogether, but is also weakening many conventional legal experts and regulators who are interested in the process, would like to engage with it but who raise critical points about the COBBES form of regulation or are not specialized in that area. Human rights advocates and lawyers, for example, often find themselves relegated to peripheral positions, as they fall outside the selfreferential circle of COBBES experts and yet work on a terrain closely related to it. ${ }^{15} \mathrm{~A}$ case in point is the shifting fortunes of the UN working group on mercenaries. It began holding a central place as a venue in which regulation could be discussed, and it continues to actively engage in reporting on and working with the regulation. However, with the emergence of alternative fora and the fragmentation of regulatory expertise, it has been excluded. For example, in relation to the ICoC process, although the UN OHCHR under which the working group is placed is based in Geneva, as are DCAF and the ICRC, who initiated and are pushing the ICoC, although the people know each other, and although the working group is interested in the ongoing process, it

\footnotetext{
14 "There is a long history of management systems standards: the infrastructure systems in place are very professionalized. This is their advantage," as DeWinter-Schmitt explained to me (2013).

${ }^{15}$ For example, in the context of US PSC standards, the Amnesty International chair of Business and Human Rights group explained that "I was participating in examining the accreditation rule. It is not a permanent role... I was the only one with HR background" (DeWinter-Schmitt, 2013).
} 
is not involved, not even in a consulting function. ${ }^{16}$ On the contrary, it is often summarily dismissed. ${ }^{17}$ Along with other specialized (non-COBBES) forms of expertise, its role in the regulatory landscape has been decidedly diminished.

In spite of the insistence on "dialogue" and "inclusiveness" in most COBBES contexts, the work of the whitelists is in sum generating an exclusive and self-referential expertise that is increasingly influential in regulatory debates. Arguably, this is precisely what pragmatic expertise is all about. It is an expertise that marginalizes experts who would take strong and hence non-pragmatic positions - like the UN working group in favour of a binding instrument for example - undermining the seemingly smooth and non-conflictual interlinking of regulatory forms. The pragmatic work done by lists is not only affecting the regulatory topology by leaving its own imprint; in the process it is also shifting the place of other experts and their expertise.

\section{The Displacement of Criticism}

A final imprint left by the whitelists is that they have restricted the scope for criticism. The emphasis placed on potential also works as a soundproofing against the disturbing noise of criticism. If indeed "the important thing is to have the standards [and] having the standards is more important than what exactly they say" (Chadwick, 2013) because they have potential, then clearly critique is difficult to wage. To become credible, criticism has to show that the alleged potential does not exist. It has to present an image of the future persuasively demonstrating that the potentiality the list opens up is either absent or, even more strongly, that allowing the work of the lists to continue would have some regrettable consequence. Constructing such an image is difficult. It requires nothing less than becoming a reader of the future, a soothsayer, to be taken seriously. This feat is formidable. It requires overcoming the positive mood, the atmosphere of optimism, which surrounds "potentiality". This includes both the positive affect generated around COBBES specifically - i.e. the promise that they will be the solution to the regulatory conundrums that mark commercial security - and the more generally positive affect generated by the idea of "potentiality" that has become a trope of contemporary management and politics (e.g. Holmqvist and Spicer, 2012). Criticism therefore begins from a singularly weak

\footnotetext{
16 "We are willing to assist if we are asked to and it is within the mandate... We are in regular contact with members. You have seen the constitution of steering committee. We could contribute if they offered" (Katz, 2013).

${ }^{17}$ Summarily, because the reasons do not stand up to scrutiny. The most common arguments are that it is associated with the UN Convention on Mercenaries, which means that its expertise is sponsored by Cuba and has nothing to do with commercial security. However, there are above one hundred signatory states, it is currently developing a binding instrument for private military companies, and the core experts in this are US and South African nationals.
} 
position. There is no need for Apollo's curse to make critics of the whitelists and the COBBES appear as the Cassandras. Potentiality does the work.

The focus on potentiality displaces critique by making its emergence less likely and the form it takes when it does emerge easier to reject. This is so strong that those observing the regulatory discussions lament the weakness/absence of Civil Society engagement. They have been surprisingly "friendly", as Joachim and Schneiker (2012) put it. Or as the Amnesty International Business and Human Rights Initiative explained with respect to the ICoC process specifically: "The civil society representation is really weak. There are tremendous shortcomings... there are no Southern states, no Southern NGOs" (DeWinter-Schmitt, 2013). At the same time a considerable number of very important civil society initiatives have formulated fundamental criticism. War on Want (2006), Human Rights First (2008), International Alert (2003), StateWatch (2010) and CorpWatch (2009) have all participated in the painstaking effort of documenting abuses and suggesting better regulations. Organizations such as the American Civil Liberties Union, The Centre for Constitutional Rights or the Centre for Public Integrity have placed the emphasis on the need for more effective legislation. ${ }^{18}$ However, these engagements are not reflected upon in the processes surrounding the COBBES. Instead, the critical work of civil society organizations is reduced to a refusal to engage, a "radical and unreasonable attitude", as a government representative at the Montreux +5 Conference put it in his response NGO criticism. ${ }^{19}$ The displacement of conventionally formulated critique as radical and unreasonable may be one of the reasons art and irony are occupying a growing space, as illustrated for example by the already cited Pink Code fake press release.

The displacement of criticism both by weakening its credibility and by dismissing it as radical and unreasonable makes it possible to present the whitelisting processes and the COBBES they refer to as if they were consensual. This consensus in turn becomes a reason for sticking to the status quo of the listing practices and for not responding to whatever critique about them transpires through the cracks in the soundproofing

\footnotetext{
${ }^{18}$ For example ACLU has looked into human trafficking by contractors and questioned the way it has been handled legally https://www.aclu.org/military-contractor-human-trafficking-foia-request and the CRR have questioned the way contractors' liability was handled legally, not only in connection to the Nisour Square shootings (where it recently won a major victory), but in many other cases, including the Abu Ghraib prisoner abuse http://ccriustice.org/ourcases/currentcases/al-shimari-v-caci-et-al.

${ }^{\frac{19}{19}}$ The exchange took place following the presentation by Patricia Feeney, Executive Director, Rights and Accountability in Development (RAID). Her presentation deplored the weak "accountability and victims' access to remedies" ensured by the Montreux Document. For the conference program see http://psm.du.edu/media/documents/international regulation/global standards codes of conduct/montreux/montreux 5 agenda.pdf.
} 
wall. As Chadwick phrased it when reflecting upon the possible inclusion of a human rights provision in the IFBEC standard:

We could be accused of not being expansive enough, not moving quickly enough. However, we would rather implement something we know everyone can agree on, dig our heels and grow slowly. That is far better than trying to achieve a perfect world tomorrow and, therefore, get no consensus and no action at all (Chadwick, 2013).

\section{Conclusion}

This article has described the politics of whitelisting in commercial security. It has shown that whitelists do extensive regulatory work: they stake out regulatory space, link different forms of regulation and they prioritize potentiality. The article has also directed attention to the traces this work leaves on the topology of regulation, suggesting that their work has devalued evidence, led to the emergence of new forms of regulatory expertise and displaced criticism. The lists are, in other words, engaged in a regulatory politics. They are reshuffling who has a say over regulation, what kinds of values and priorities regulation is expressing and reproducing, and, perhaps most profoundly, they are refashioning the possibilities of contesting, resisting or just simply debating these changes.

This account pays homage to a classical insight, the insight that power is never as effective as when it is there for all to see, visibly marking the landscape but so much taken for granted that it is left unquestioned. Veyne's analysis of Trajan's Column in Rome makes this classical point wonderfully. In an essay commissioned to celebrate the uncovering the column following major restoration work, Veyne provocatively argues that the column is not supposed to be seen. It stands in the middle of Rome objectifying and reproducing a power that there is no need to scrutinize and that one is not even expected to want to scrutinize. Who could see the tiny details at the top of a 35-metre-high column? Or even those close to its bottom at 2 metres? Certainly, the column discourages any attempt to even try. The column reproduces inscrutable power (Veyne, 2011: 40). The argument here has been that whitelists have an analogous role for the power of the COBBES. They are visible for everyone to see, but their details are not meant to be looked at. They reproduce inscrutable power. However, there is an obvious difference between Trajan's column and whitelists in commercial security. The column stands towering, incarnating the unified power of the emperor it reproduces. The whitelists are scattered all over the regulatory landscape in the image of the market form of governance they reproduce. They are minions of sorts. Just as their many disjointed, disorganized and dispersed activities make the infernal 
alternatives that reproduce the spell of capitalism, so the whitelists reproduce the infernal alternative of softly regulated security markets. The scattered presence of the whitelists lends power to their politics, as it becomes difficult to capture and contest.

This article has described that power and hence the politics of whitelisting. This politics should pass neither unscrutinized nor uncontested but deserves engagement. However, for such engagement to take shape, recognizing the role and responsibility of whitelists is paramount. This requires no conspiracy theory, no looking behind, but a willingness to look closely at and describe what is unfolding before our eyes. Looking closely at whitelists might be important well beyond commercial security. While extensive attention has been paid to blacklists and their politics, whitelists are more rarely studied. Yet, they figure prominently in relation to codes and standards beyond commercial security, and perhaps most commonly in the regulation of the internet. Through Wikileaks and Snowden we have learnt of the important place whitelists held in granting intelligence agencies access to data (Devine-Mansfield, 2009; Lawson, 2008). Inversely we also know that the whitelists of websites that control searches and readings in public libraries play an important role in defining what readers are granted access to (Nunziato, 2005). While these cases are already contentious and contested, recognizing the work done by whitelists and the imprint it leaves on regualtory topologies may also help in engaging their politics elsewhere. Such, at least, the etcetera this article concludes on.

\section{References}

Abbott A, 1988 The System of Professions: An Essay on the Division of Expert Labor (The University of Chicago Press, Chicago)

Beerli C, 2013 Key note adress [by vicepresident of ICRC]: Private military/security companies: Rules should be implemented. Montreux +5 Conference Montreux, Switzerland (11-13 December 2013)

Boltanski L, 2012 Enigmes et Complot: Une Enquête à Propos d'Enquêtes (Gallimard, Paris)

Bowker G, Star S L, 2000 Sorting Things Out: Classification and Its Consequences (MIT Press, Boston)

Callon M, 2008 "Economic Markets and the Rise of Interactive Agencements: From Prosthetic Agencies to Habilitated Agencies", in Living in a Material World: Economic Sociology Meets Science and Technology Studies1 Eds T Pinch, R Swedberg (Massachusets Institute of Technology, Boston) pp 29-56 
Chadwick C D, 2013 "Interview about listing practices in the commercial security industry", (formerly Chair of the International Forum on Business Ethical Conduct (IFBEC) and BAE Systems, Inc., Vice President, Contracts and Business Conduct)

Code Pink, 2007 "Blackwater USA Unveils New Corporate Integrity Department" http://www.codepink4peace.org

CorpWatch, 2009 Halliburton's Army: How A Well-Connected Texas Oil Company Revolutionized The Way America Makes War (Nation Books) http://www.corpwatch.org/article.php?id=15287

DeLanda M, 2006 A New Philosophy of Society: Assemblage Theory and Social Complexity (Continuum, London and New York)

Devine-Mansfield S, 2009 "The promise of whitelisting" Network Security June 4-6

DeWinter-Schmitt R, 2013 "Interview about listing practices in the commercial security industry", (Co-Director, Initiative for Human Rights in Business, Center for Human Rights and Humanitarian Law, American University Washington College of Law and Co-Chair, Business and Human Rights Group, Amnesty International USA)

Dickinson L A, 2005 "Government for Hire: Privatizing Foreign Affairs and the Problem of Accountability under International Law" William \& Mary Law Review 47 135-237

Eco U, 2009 The Infinity of Lists. From Homer to Joyce (MacLehose Press, London)

Fischer-Lescano A, Teubner G, 2004 "Regime-Collisions: The Vain Search for Legal Unity in the Fragmentation of Global Law" Michigan Journal of International Law 25 999-1045

Fuller M, 2005 Media Ecologies: Materialist Energies in Art and Technoculture (MIT Press, Cambridge MA)

Gond J-P, Kang N, Moon J, 2012 "The Government of Self-Regulation: On the Comparative Dynamics of Corporate Social Responsibility" Economy and Society 40 (4) 640-671

Goody J, 1977 The Domestication of the Savage Mind (Cambridge University Press, Cambridge)

Holmqvist M, Spicer A, 2012 The Ambidextrous Employee: Exploiting and Exploring People's Potential (Emerald Group Publishing Limited)

Human Rights First, 2008 "Private Security Contractors at War: Ending the Culture of Impunity", www.humanrightsfirst.org 
International Alert, 2003 Private Military Companies and the Proliferation of Small Arms: Regulating the Actors (British American Security Information Council, http://www.international-alert.org/pdf/pubsec/Btb brf10.pdf) International Consortium of Investigative Journalists, 2002 "Making a Killing: The Business of War" http://www.publicintegrity.org/dtaweb/ICIJ BOW.ASP?Section=Chapter\&ChapNum=1

Joachim J, Schneiker A, 2012 "Warum so freundlich? Der Umgang von NGOs mit Privaten Sicherheits- und Militärfirmen", in Sicherheitskultur. Analysen zur sozialen Praxis der Gefahrenabwehr Eds C Daase, P Offermann, V Rauer pp 277-300

Katz A, 2013 "Interview about listing practices in the commercial security industry", (Member of the Cape and New York Bars Chair Rapporteur, United Nations Human Rights Council Working Group on Mercenaries) Latour B, 2005 Re-assembling the Social. An Introduction to Actor Network Theory (Oxford University Press, Oxford)

Latour B, 2010 The Making of Law: An Ethnography of the Conseil d'Etat [La fabrique du droit] (Polity Press, Oxford)

Lawson B, 2008 "What not to "Ware": As Congress Struggles against Spyware, the FBI Develops its Own" Rutgers Computer and Technology Law Journal 35 77-102

Leander A, 2009 “New Roles for External Actors? Disagreements about International Regulation of Private Armies" in War and Peace in Transition: Changing Roles for External Actors Eds K Aggestam and A Björkdal (Nordic Academic Press , Lund) pp 32-52

Leander A, 2012 "What Do Codes of Conduct Do? Hybrid Constitutionalization and Militarization in Military Markets" Global Constitutionalism 1 (1) 91-119

Leander A, 2013 "Targeted Killings and Extrajudicial Executions: Technological Agency in the Politics of Legal Expertise" Leiden Journal of International Law 26 (4) 811 - 831

Leyshon A, Thrift N, 2009 "Lists come alive: eletronic systems of knowledge and the rise of credit-scoring in retail banking" Economy and Society 28 (3) 434-466

Miller D, 1998 A theory of shopping (Cambridge University Press, Cambridge and New York)

Nunziato D, 2005 "The Death of the Public Forum in Cyberspace" Berkeley Technology Law Journal 20 11151171 
Palma D A, 2010 Borges.com. La ficción de la filosofia, la política y los medios (Editorial Biblos, Buenos Aires)

Pignarre P, Stengers I, 2011 Capitalist sorcery : breaking the spell (Palgrave Macmillan, Houndmills, Basingstoke)

Salzmann B, 2013 "Interview about listing practices in the commercial security industry" (ADS, Trade Organisation for the UK Aerospace Defence, Security and Space industries; Director - Overseas \& Exports)

Staeheli U, 2012 "Listing the global: dis/connectivity beyond representation?" Distinktion: Scandinavian Journal of Social Theory 13 (3) 233-246

Star S L, 2010 "This is Not a Boundary Object: Reflections on the Origin of a Concept" Science, Technology, \& Human Values 35 (5) 601-617

Stark D, with, Beunza D, Girard M, Lukacs J, 2009 The Sense of Dissonance: Accounts of Worth in Economic Life (Princeton University Press, Princeton)

StateWatch, 2010 "NeoConOpticon: The EU Security-Industrial Complex" (Statewatch, London) Stengers I, 1995 L'invention des sciences modernes [original edition 1993 (Flammarion, Paris)

Taussig M, 2004 My Cocaine Museum (University of Chicago Press, Chicago)

Teubner G, 2011, "Self-Constitutionalizing TNCs? On the Linkage of 'Private' and 'Public' Corporate Codes of Conduct" Indiana Journal of Global Legal Studies 17 17-38

van Amstel N, 2013 "Interview about listing practices in the commercial security industry" (DCAF [Democratic Control over Armed Forces] Project Officer Operations IV)

Veyne P, 2011 "Propagande expression roi, image idole oracle" in Propagande expression roi, image idole oracle. Visibilité et lisibilité des images du pouvoir Eds L Marin, P Veyne (Les éditions arché, Paris) Wacquant L, 2005 Pierre Bourdieu and Democratic Politics. The Mystery of Ministry (Polity Press, Cambridge) War on Want, 2010 Stop the Business of War http://old.waronwant.org/campaigns/corporations-and-conflict 